\title{
Agro-Meteorological Studies in Different Cotton Species under HDPS
}

\author{
A.P. Karunakar*, Arvind Kumar, A.B. Turkhede, M.B. Nagdeve and R.S. Mali \\ All India Co-ordinated Research Project for Dryland Agriculture (Agrometeorology), Dr. \\ Panjabrao Deshmukh Krishi Vidyapeeth, Akola (MS) - 444104, India \\ *Corresponding author
}

\begin{tabular}{|l|}
\hline Ke y w o r d s \\
Phenology, Radiation, \\
$\begin{array}{l}\text { Canopy temperature, } \\
\text { Chlorophyll content, } \\
\text { Thermal units }\end{array}$ \\
\hline Article Info \\
\hline $\begin{array}{l}\text { Accepted: } \\
\text { 26 July 2018 } \\
\text { Available Online: } \\
10 \text { August } 2018\end{array}$ \\
\hline
\end{tabular}

\section{A B S T R A C T}

Planting density is the most active factor and plays pivotal role in crop management practices. Hence plant density is the enduring topic for crop production improvement. The rational plant population is an important attribute to high yield of cotton, because it can provide a beneficial micro-environment within the canopy for plant growth and development as well as yield formation. A field investigation was carried out at the field of All India Coordinated Research Project on Agro-meteorology, Dr. Panjabrao Deshmukh Krishi Vidyapeeth, Akola (MS) during Kharif season of 2015-16. Three cotton genotypes viz. G.hirsutum cotton AKH-081, G. arboretum cotton AKA-7 and G. hirsutum hybrid Bt. cotton Balwan with three plant densities with the population level of 100,150and 200 per cent of normal for respective genotypes were laid out in Factorial Randomized Block Design with three replications. The results revealed that, cotton genotype $G$. arboreum AKA-7 with 150 to 200 per cent planting density recorded maximum fraction of PAR, lowest fraction of transmitted PAR and canopy temperature with high canopy temperature depression and greater tolerance to environment stress with comparative to genotypes AKH-081 and Bt. cotton Balwan recorded significantly higher number of picked bolls, boll weight, higher seed cotton weight and harvest index (17.59 g, $3.21 \mathrm{~g}, 56.49 \mathrm{~g}$ and $39.50 \%)$ as compared to genotype AKA-7 and genotype AKH-081. However, AKA-7 registered significantly higher seed cotton yield, cotton stalk yield and biological yield (1715, 3038 and 4753 $\mathrm{kg} \mathrm{ha}^{-1}$ ) than Bt. cotton Balwan and hirsutum cotton genotype AKH-081. Normal plant density recorded higher number of picked bolls plant ${ }^{-1}$, seed cotton weight plant ${ }^{-1}$ (11.67 and $33.97 \mathrm{~g}$ ) which are significantly more over high planting density of 150 and 200 per cent of normal population. However, normal planting at 100,150 and 200 per cent population was recorded being at par. High density planting (200 per cent of normal density) produced maximum seed cotton yield, cotton stalk yield and biological yield i.e. 1802,3338 and $5140 \mathrm{~kg} \mathrm{ha}^{-1}$, respectively. Whereas, high density planting at 100 per cent of normal density produced maximum harvest index (38.08 $\%)$ which are significantly higher than 200 per cent high density planting (35.07\%) an statistically at par with high density planting of 150 per cent. Different cotton genotype as well as plant density were statistically not significant in respect of quality studies of cotton. 


\section{Introduction}

Planting density is the most active factor and plays pivotal role in crop management practices; hence plant density is the enduring topic for crop production improvement. The rational plant population is an important attribute to high yield of cotton, because it can provide a beneficial micro environment within the canopy for plant growth and development as well as yield formation. Hence increasing plant population could be one of the most effective ways of improving yield. This system gained further acceptance after the introduction of cotton hybrids. Similar, research experiments conducted later indicated that with increase in plant density yield per unit area increased to an upper limit (optimum) plateaued later and ultimately decline. The optimum plant density in this parabolic (density-yield) relationship was a function of the genotype, soil type, climate and management. Before the advent of hybrid cotton, the highest plant density recommended for varieties of G.hirsutum were 55000 plants ha $^{-1}$ (Bonde and Raju, 1996). Rainfed cotton production has direct bearing on the agrarian economy of the region. Recent years have seen decline in cotton sowing and its stagnated rate of growth and productivity due to many reasons like monsoon vagaries, abiotic stress during the critical crop growth phase, poor agronomical practices like sub optimal plant population, imbalance fertilizers, use of low quality seed, conventional sowing methods, high weed infestation, boll shedding due to high temperature late in the season, flare half of insect pressure, etc.

Crop yield depends on a canopy's capacity to intercept and efficiently use solar radiation. Photo-synthetically Active Radiation (PAR) represents the solar radiation that can be absorbed by green plants and use for photosynthesis to produce biomass. Canopy temperature measurements have been widely used in recent years to study genotypic response to drought. Canopy temperature and canopy air temperature difference are directly related to the amount of water present in the plant (Buttar et al., 2005). Canopy temperature depression, the difference between air temperature and canopy temperature is positive when the canopy is cooler than the air. It has been use in various practical applications including the evaluation of plant response to environmental stress. Chlorophyll maintenance and consequently photosynthesis durability in stress conditions are among physiological indicators of stress resistance (Zhang et al., 2006). With above background and emphasis the research project was undertaken with following objectives: $i$. to study the morphology, phenology and to understand the relationship between plant density and canopy environment in cotton genotypes viz. $G$. Arboretum AKA-7, $G$. hirsutum AKH-081 and G. hirsutm hybrid Bt. cotton Balwan under HDPS.

\section{Materials and Methods}

A field investigation was carried out at All India Coordinated Research Project on Agrometeorology, Dr. Panjabrao Deshmukh Krishi Vidyapeeth, Akola (MS) during Kharifseason of 2015-16. Three cotton genotypes viz., $G$. hirsutum cotton AKH-081, G.arboreum cotton AKA-7 and G. hirsutum hybrid Bt. Balwan with three plant densities at the population level of $100 \%$ normal planting, $150 \%$ high density planting and 200\% high density planting of normal for respective genotypes were laid out in FRBD with three replications. Soil of experimental plot was medium deep black. Cotton crop was sown on $18^{\text {th }}$ June, 2015. Total rainfall of $590.8 \mathrm{~mm}$ was recorded during the crop growing season.

Line quantum sensor (LI-1400) was used to record the intercepted and transmitted PAR (Photo-Synthetically Active Radiation) as a 
top as well as bottom of the crop canopy. Fraction of the intercepted PAR (FIPAR) and transmitted PAR (FTPR) was calculated from the intensity of radiations recorded at the top and bottom of crop canopy and expressed by formula:

Fractional intercepted PAR $($ FIPAR $)=$ PARiPARt/PARi

Where,

PARi is the incident PAR $20 \mathrm{~cm}$ above the canopy and

PARt is transmitted PAR at the bottom of the canopy $20 \mathrm{~cm}$ from soil surface.

Canopy temperature measurements were made by infrared thermometer in ${ }^{0} \mathrm{C}$ which was focused on 10:1 and at clear weather period (13.00 to $14.00 \mathrm{hrs}$ ) and (CT) and Canopy temperature depression (CTD) is difference between air (Ta) and canopy (Tc) and it is positive (more) when the canopy is cooler than the air.

Chlorophyll content index using a portable chlorophyll meter (CCM 200 plus) was recorded at 60, 90 and 120 DAE. The observations were recorded during the day time 11.00 to $14.00 \mathrm{hrs}$ from three representative leaves from bottom middle and top portion of the plant.

Thermal unit was calculated from daily weather data on maximum and minimum temperature:

Thermal unit requirement $\left({ }^{0} C\right.$ day $)=(T \max$ $+T \mathrm{~min} / 2)$ - $T$ base

Where,

T max- Maximum temperature

Tmin- Minimum temperature
$\mathrm{T}$ base- Base temperature at $15^{\circ} \mathrm{C}$.

Thermal use efficiency $\left(\mathrm{kg} \mathrm{ha}{ }^{-10} \mathrm{C}\right.$ day $^{-1)}$ of crop in terms of seed cotton yield and biomass yield was computed treatmentwise by dividing seed cotton yield and biomass yield by corresponding accumulated thermal units (GDD of the treatment) of the treatment.

Seed cotton yield/Biological yield $\left(\mathrm{kg} \mathrm{ha}^{-1)}\right.$ Thermal use efficiency $\left(\mathrm{kgha}^{-10} \mathrm{C}\right.$ day $^{-1)}=$ Accumulated Thermal Units $\left({ }^{0} \mathrm{C}\right.$ day $\left.^{-1}\right)$

\section{Results and Discussion}

\section{Crop Phenology}

Genotype Bt. cotton Balwan required more days to first square (51.2) than the other two genotypes AKA-7 (50.2) and AKH-081 (47.9). Genotype AKH-081 produced early flowering (67.9 days) followed by genotypes AKA-7 (69.1) and Balwan (69.1). First boll burst was observed earlier with genotype AKH-081 (116.1) than genotype Balwan (118.1) and AKA-7 (122.2). Genotype AKA-7 required more number of days to first boll burst stage because it suffered marginal square/flower drop of first flush. Though genotype AKH-081 also encountered scattered square/flower drop of first flush. Days required for first picking were $\mathrm{AKH}-081$ (128.7) followed by Balwan (131.7) and AKA-7 (138.1). Due to delay in first boll burst genotype AKA-7 required more days to first picking. Genotype AKH-081 reached to final picking stage earlier (178.0 days) than Balwan (180.7) and AKA-7 (191.3). Due to earliness of respective phenophase, genotype AKH-081 reached earlier to final picking than the rest of the genotypes. Although average crop duration of all three genotypes is in the range of 150160 days, increased duration observed in the present study might be due to the seasonal growing environment influences. As such the 
variation in occurrence time of respective phenophase and also crop duration among genotypes are primarily due to their different inherent genetic expression, though modified and controlled by growing environment influences.

Normal planting density (100\%) required comparatively more number of days to attain different phenophase and reach maturity. Plants in thin stands grow large vegetative structures and more fruit load, as a result more time is required to set the crop and consequently maturity is delayed. There appears marginal difference (1 to 2 days) between 100and $150 \%$ planting density in attainment of respective phenophase and maturity. In comparison with normal planting density (100\%) highest planting density of (200\%) of normal population reached earlier to first flower (1 day), first boll burst (3 days), first picking (4 days) and final picking (6 days). According to Munir et al., (2015) number of days from planting to first floral bud initiation (squaring) was decreased by narrow spacing which might be due to increased interplant competition. These results also substantiated the findings of Bednarz et al., (2000) and Mygdakos et al., (2004), who reported that the earliness (early squaring or flowering) increased when row spacing decreased.

\section{Radiation interception}

Fraction of intercepted PAR was more in arboreum AKA-7 and hirsutum AKH-081 cotton genotypes than in Bt. cotton Balwan. Transmitted PAR was lowest in AKA-7 and maximum under widely spaced Bt.cotton Balwan. Genotype AKA-7 is conventionally closely spaced with higher population density per unit area (higher LAI), which goes still higher under high density planting. Similar in the case with AKH-081 genotype as well. Comparatively genotype Bt. cotton Balwan is much widely spaced and has noticeably lower population density per unit area (lower LAI), conventionally and with high density planting as well. Naturally, cotton genotypes AKA-7 and $\mathrm{AKH}-081$ closes the canopy faster than widely spaced genotype Balwan leading to greater light interception. However, after canopy closure the dense canopy of these genotypes allow less light penetration through the canopy Rose et al., (2003) pointed out that in ultra-narrow row planting though leaf area development continued after canopy closure, which meant the crop was producing new leaves, that were not increasing light interception and were shading leaves lower in the canopy. As a consequence fraction of transmitted PAR is lowered with crop growth stage as was observed in AKA-7 and AKH081 genotypes.

Across the observed stages of growth, fraction of intercepted PAR (IPAR) was comparatively more and fraction of transmitted PAR (TPAR) was less with increased plant density from 100 to $200 \%$. Transmission within the canopy bottom decreased with increasing density. Higher plant densities had greater LAI than the lower plant density causing more interception of incident radiation. However, high density planting had earlier canopy development and consequently poorer light distribution in the canopy and hence lower fraction of transmitted PAR due to mutual shading of leaves. Crop growth stage of 60 DAE coincided with squaring to first flower phase with high transmittance while $90 \mathrm{DAE}$ onwards coinciding with boll setting period had low transmittance. So less light was available to leaves in the canopy that is important for supporting boll growth. This may be one reason why boll size is smaller despite there being fewer bolls per plant (Rose et al., 2003). However, the increased number of plants in high density planting compensates for smaller boll size. Yang et al., (2014) also observed that light transmittance in negatively 
correlated to canopy closure and squaring period had the highest transmittance while boll setting period had lowest transmittance. Pettigrew et al., (2013) reported that the extra plants in the high plant density increased the LAI throughout the growing season and further allowed this plant density to intercept more early season light than the low plant density. Despite these apparent advantages for the high plant density, higher extinction coefficients for the low plant density indicate that those canopies were efficient in intercepting sunlight per unit LAI than the higher density canopies.

\section{Canopy temperature and canopy temperature depression}

Canopy temperature at all the stages of observation was lowest in AKA-7 with high canopy temperature depression, this indicating comparatively lower degree of field scale plant water stress in this genotype indicative of greater tolerance of AKA-7 to environmental stress than other two genotypes AKH-081 and Bt. Balwan. These results support the findings of Yang et al., (2014) that the crop varieties with lower canopy temperature had a higher yield resulted from slower declining tendency in chlorophyll and soluble protein content after the peak, higher enzyme activities of SOD and NR and lower MDA content in cotton (Han et al., 2007).

At 60 DAE, lowest canopy temperature (CT) and highest canopy temperature depression was observed in high density planting at $150 \%$ population level. At 90 and 120 DAE, high density planting at $200 \%$ population level indicated maximum $\mathrm{CT}$ and lowest CTD followed by high density planting at $150 \%$ population level and normal $100 \%$ planting density. In a dense stand excess competition for resources, particulars soil moisture, reduces share of each plant reducing its hydration status, causing higher canopy temperatures. According to Yang et al., (2014), heavy vegetation was slow in canopy air circulation with high relative humidity, resulting in higher canopy temperature.

\section{Chlorophyll content index}

Chlorophyll index among different cotton genotypes were statistically not significant. Numerically, no definite trend prevailed among the genotypes as AKA-7 (37.38\%), Balwan (39.82\%) and AKH-081 (38.23\%) measured maximum value, respectively at 60 , 90 and 120 DAE.

Different plant densities had no significant influence on chlorophyll index. But numerically normal planting density NP-100\% recorded maximum chlorophyll index at all the stages of observation followed by high densities of $150 \%$ and $200 \%$. This could be reflection of better resources availability to growing plants under normal population density. Jahedi et al., (2013) also observed that the effect of row spacing on chlorophyll index was not significant. Interaction effect was found to be not significant.

\section{Thermal unit}

Among the genotypes the maximum thermal units were accumulated by AKA-7 $\left(2273.2{ }^{0} \mathrm{C}\right.$ day) and it was followed by Balwan (2222.3 ${ }^{0} \mathrm{C}$ day) and $\mathrm{AKH}-081$ (2190.2 ${ }^{0} \mathrm{C}$ day $)$.

Crop grown with normal population density (NP-100\%) accumulated higher thermal units $\left(2253.3{ }^{0} \mathrm{C}\right.$ day) followed by high plant population densities at $150 \%\left(2241.9{ }^{\circ} \mathrm{C}\right.$ day $)$ and $200 \%$ (2190.5 ${ }^{0} \mathrm{C}$ day). Comparatively longer total growth duration of the crop in the respective genotype and plant density caused higher accumulation of thermal units. Cotton growth and development relates with the amount of heat which the plant is exposed (Clay et al., 2006). 
Table.1 Crop phenology as influenced by different treatments

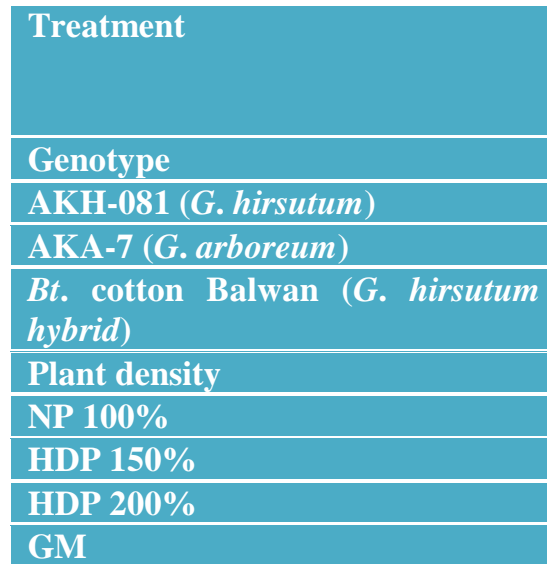

\begin{tabular}{|c|c|c|c|c|}
\hline \multicolumn{5}{|c|}{ Duration (days) } \\
\hline $\begin{array}{c}\text { First } \\
\text { square }\end{array}$ & $\begin{array}{l}\text { First } \\
\text { flower }\end{array}$ & $\begin{array}{c}\text { First boll } \\
\text { burst }\end{array}$ & $\begin{array}{c}\text { First } \\
\text { picking }\end{array}$ & $\begin{array}{c}\text { Final } \\
\text { picking }\end{array}$ \\
\hline 47.9 & 67.9 & 116.1 & 128.7 & 178.0 \\
\hline 50.2 & 39.1 & 122.2 & 138.1 & 191.3 \\
\hline 51.2 & 69.1 & 118.1 & 131.7 & 180.7 \\
\hline 50.4 & 69.2 & 120.3 & 134.3 & 186.0 \\
\hline 49.6 & 69.1 & 119.2 & 133.6 & 184.3 \\
\hline 49.3 & 67.8 & 116.9 & 130.6 & 179.7 \\
\hline 49.8 & 68.7 & 118.8 & 132.8 & 183.3 \\
\hline
\end{tabular}

Table.2 Fraction of intercepted and transmitted PAR as influence by different treatments

\begin{tabular}{|l|}
\hline Treatment \\
\hline Genotype \\
\hline AKH-081 (G. hirsutum) \\
\hline AKA-7 (G. arboreum) \\
\hline $\begin{array}{l}\text { Bt. cotton Balwan (G.hirsutum } \\
\text { hybrid) }\end{array}$ \\
\hline Plant density \\
\hline NP 100\% \\
\hline HDP 150\% \\
\hline HDP 200\% \\
\hline GM \\
\hline
\end{tabular}

\begin{tabular}{|c|c|c|c|c|c|c|}
\hline \multicolumn{2}{|c|}{60 DAE } & \multicolumn{2}{c|}{90 DAE } & \multicolumn{2}{c|}{120 DAE } \\
\hline FIPAR & FTPAR & FIPAR & FTPAR & FIPAR & FTPAR \\
\hline 0.57 & 0.43 & 0.69 & 0.31 & 0.74 & 0.26 \\
\hline 0.64 & 0.36 & 0.73 & 0.27 & 0.75 & 0.25 \\
\hline 0.39 & 0.61 & 0.60 & 0.40 & 0.63 & 0.37 \\
\hline & & & & & \\
\hline 0.48 & 0.52 & 0.62 & 0.38 & 0.66 & 0.34 \\
\hline 0.52 & 0.48 & 0.67 & 0.33 & 0.70 & 0.30 \\
\hline 0.61 & 0.39 & 0.73 & 0.27 & 0.76 & 0.24 \\
\hline $\mathbf{0 . 5 3}$ & $\mathbf{0 . 4 7}$ & $\mathbf{0 . 6 7}$ & $\mathbf{0 . 3 3}$ & $\mathbf{0 . 7 1}$ & $\mathbf{0 . 2 9}$ \\
\hline
\end{tabular}

Table.3 Canopy temperature and canopy temperature depression as influence by different treatments

\begin{tabular}{|l|}
\hline Treatment \\
\hline Genotype \\
\hline AKH-081 (G. hirsutum) \\
\hline AKA-7 (G. arboreum) \\
\hline $\begin{array}{l}\text { Bt. cotton Balwan (G. hirsutum } \\
\text { hybrid) }\end{array}$ \\
\hline Plant density \\
\hline NP 100\% \\
\hline HDP 150\% \\
\hline HDP 200\% \\
\hline GM \\
\hline
\end{tabular}

\begin{tabular}{|c|c|c|c|c|c|}
\hline \multicolumn{2}{|c|}{60 DAE } & \multicolumn{2}{c|}{90 DAE } & \multicolumn{2}{c|}{120 DAE } \\
\hline CT & CTD & CT & CTD & CT & CTD \\
\hline 30.5 & 2.5 & 27.7 & 4.9 & 32.6 & 4.2 \\
\hline 30.0 & 3.0 & 27.1 & 5.5 & 32.4 & 4.4 \\
\hline 30.9 & 2.1 & 27.8 & 4.8 & 33.0 & 3.8 \\
\hline & & & & & \\
\hline 30.6 & 2.4 & 27.1 & 5.5 & 32.2 & 4.6 \\
\hline 30.1 & 2.9 & 27.3 & 5.3 & 32.5 & 4.3 \\
\hline 30.6 & 2.9 & 28.2 & 4.4 & 33.2 & 3.6 \\
\hline 30.5 & 2.5 & 27.5 & 5.1 & 32.7 & 4.1 \\
\hline
\end{tabular}


Table.4 Chlorophyll content index (\%) as influenced by different treatments

\begin{tabular}{|l|}
\hline \multicolumn{1}{|l|}{ Treatments } \\
\hline Genotype \\
\hline AKH-081 (G. hirsutum) \\
\hline AKA-7 (G. arboreum) \\
\hline Bt. cotton Balwan (G. hirsutum hybrid) \\
\hline S.Em. \pm \\
\hline CD at 5\% \\
\hline Plant density \\
\hline NP 100\% \\
\hline HDP 150\% \\
\hline HDP 200\% \\
\hline S.Em. \pm \\
\hline CD at $5 \%$ \\
\hline Interaction \\
\hline S.Em. \pm \\
\hline CD at $5 \%$ \\
\hline GM \\
\hline
\end{tabular}

\begin{tabular}{|c|c|c|}
\hline \multicolumn{3}{|c|}{ Chlorophyll content index (\%) } \\
\hline 60 DAE & 90 DAE & 120 DAE \\
\hline & & \\
\hline 37.11 & 39.17 & 38.23 \\
\hline 37.38 & 38.97 & 38.20 \\
\hline 36.08 & 39.82 & 37.81 \\
\hline 0.62 & 1.13 & 1.02 \\
\hline NS & NS & NS \\
\hline & & \\
\hline 37.18 & 40.04 & 38.60 \\
\hline 36.77 & 39.41 & 38.11 \\
\hline 36.62 & 38.50 & 37.53 \\
\hline 0.62 & 1.15 & 1.02 \\
\hline NS & NS & NS \\
\hline & & 1.76 \\
\hline 1.08 & 1.95 & NS \\
\hline NS & NS & 38.08 \\
\hline 36.86 & 39.32 & \\
\hline
\end{tabular}

Table.5 Thermal unit and thermal use efficiency as influenced by different treatments

\begin{tabular}{|l|}
\multicolumn{2}{|c|}{ Treatment } \\
\hline Genotype \\
\hline AKH-081 (G. hirsutum) \\
\hline AKA-7 (G. arboreum) \\
\hline Bt. cotton Balwan (G. hirsutum hybrid) \\
\hline Plant density \\
\hline NP 100\% \\
\hline HDP 150\% \\
\hline HDP 200\% \\
\hline GM
\end{tabular}

\begin{tabular}{|c|c|}
\hline \multicolumn{2}{|c|}{ Thermal Unit and Thermal Use Efficiency } \\
\hline Thermal unit & Thermal use efficiency \\
\hline 2190.2 & $0.67(1.92)$ \\
\hline 2273.2 & $0.76(2.09)$ \\
\hline 2222.3 & $0.71(1.81)$ \\
\hline 2253.3 & $0.58(1.53)$ \\
\hline 2241.9 & $0.75(1.99)$ \\
\hline 2190.5 & $0.82(2.35)$ \\
\hline 2258.56 & $0.71(1.94)$ \\
\hline
\end{tabular}

(Figure in parenthesis indicates thermal use efficiency in terms of biomass)

Table.6 Number of picked bolls plant ${ }^{-1}$, boll weight and seed cotton weight plant $^{-1}$ as influenced by various treatments

\begin{tabular}{|c|c|c|c|}
\hline Treatment & $\begin{array}{c}\text { Number of picked bolls } \\
\text { plant }^{-1}\end{array}$ & $\begin{array}{l}\text { Boll weight } \\
(\mathrm{g})\end{array}$ & $\begin{array}{l}\text { Seed cotton weight } \\
\left(\mathrm{g} \text { plant } \mathrm{t}^{-1}\right)\end{array}$ \\
\hline \multicolumn{4}{|l|}{ Genotype } \\
\hline AKH-081 (G. hirsutum) & 5.58 & 2.10 & 11.44 \\
\hline AKA-7 (G. arboreum) & 6.78 & 2.01 & 14.34 \\
\hline Bt. cotton Balwan (G. hirsutum hybrid) & 17.59 & 3.21 & 56.49 \\
\hline S.Em. \pm & 0.38 & 0.09 & 0.77 \\
\hline CD at $5 \%$ & 1.14 & 0.27 & 2.32 \\
\hline \multicolumn{4}{|l|}{ Plant density } \\
\hline NP $100 \%$ & 1.67 & 2.65 & 33.97 \\
\hline HDP $150 \%$ & 9.77 & 2.56 & 27.44 \\
\hline HDP 200\% & 8.51 & 2.11 & 20.87 \\
\hline S.Em. \pm & 0.38 & 0.09 & 0.77 \\
\hline CD at $5 \%$ & 1.14 & 0.27 & 2.32 \\
\hline \multicolumn{4}{|l|}{ Interaction } \\
\hline S.Em. \pm & 0.66 & 0.16 & 1.34 \\
\hline CD at $5 \%$ & NS & NS & 4.01 \\
\hline$\overline{\text { GM }}$ & 9.98 & 2.44 & 27.42 \\
\hline
\end{tabular}


Table.7 Seed cotton yield, biological yield and harvest index as influenced by different treatments

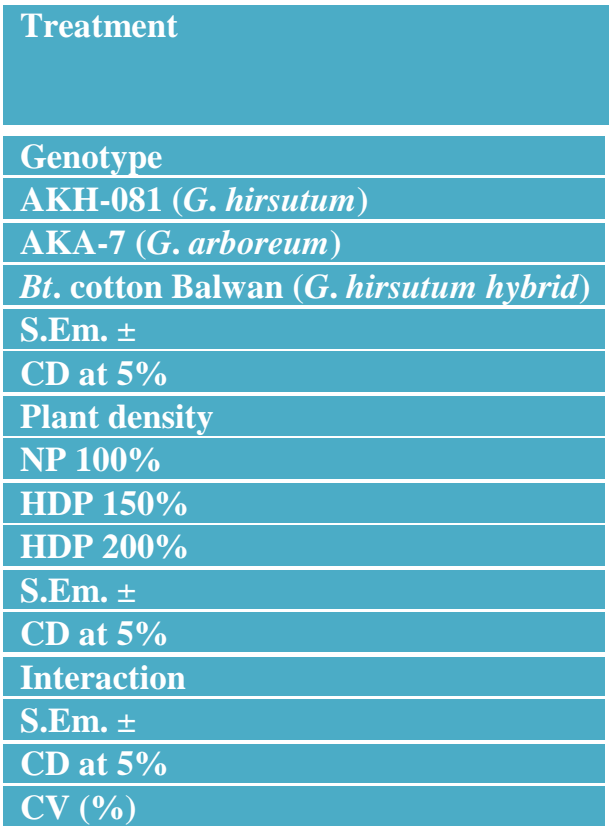

\begin{tabular}{|c|c|c|c|}
\hline $\begin{array}{c}\text { Seed Cotton } \\
\text { yield } \\
\left(\mathrm{kg} \mathrm{ha}^{-1}\right)\end{array}$ & $\begin{array}{c}\text { Cotton Stalk } \\
\text { Yield } \\
\left(\mathrm{kg} \mathrm{ha}^{-1}\right)\end{array}$ & $\begin{array}{c}\text { Biological } \\
\text { Yield } \\
\left(\mathrm{kg} \mathrm{ha}^{-1}\right)\end{array}$ & $\begin{array}{c}\text { Harvest } \\
\text { Index }\end{array}$ \\
\hline 1466 & 2718 & 4184 & 35.12 \\
\hline 1715 & 3038 & 4753 & 36.31 \\
\hline 1571 & 2443 & 4014 & 39.50 \\
\hline 46 & 90 & 130 & 0.48 \\
\hline 138 & 271 & 391 & 1.44 \\
\hline 1271 & 2080 & 3351 & 38.08 \\
\hline 1679 & 2781 & 4460 & 37.77 \\
\hline 1802 & 3338 & 5140 & 35.07 \\
\hline 46 & 90 & 130 & 0.48 \\
\hline 138 & 271 & 391 & 1.44 \\
\hline & & & \\
\hline 79 & 156 & 226 & 0.83 \\
\hline NS & NS & NS & NS \\
\hline 8.69 & 10.44 & 9.36 & 3.88 \\
\hline
\end{tabular}

Table.8 Quality parameters as influenced by different treatments

\begin{tabular}{|c|c|c|c|c|c|c|c|}
\hline Treatment & $\begin{array}{c}\text { Ginning } \\
\text { Outturn } \\
(\%)\end{array}$ & $\begin{array}{c}\text { Seed } \\
\text { Index } \\
(\mathrm{g})\end{array}$ & $\begin{array}{l}2.5 \% \text { Staple } \\
\text { Length } \\
\text { (mm) }\end{array}$ & $\begin{array}{l}\text { Uniformit } \\
\text { y Index } \\
(\%)\end{array}$ & $\begin{array}{l}\text { Micronaire } \\
\left(\mu \mathrm{g} \text { inch }^{-1}\right)\end{array}$ & $\begin{array}{l}\text { Bundle } \\
\text { Strength } \\
\left(\mathrm{g} \mathrm{tex}^{-1}\right)\end{array}$ & $\begin{array}{c}\text { Elongatio } \\
\text { n \% }\end{array}$ \\
\hline \multicolumn{8}{|l|}{ Genotype } \\
\hline AKH-081 (G. hirsutum) & 38.92 & 7.64 & 27.23 & 83.42 & 4.59 & 26.89 & 5.61 \\
\hline AKA-7 (G. arboreum) & 40.11 & 6.10 & 27.21 & 83.31 & 4.83 & 27.94 & 5.89 \\
\hline $\begin{array}{l}\text { Bt. cotton Balwan } \\
\text { (G. hirsutumhybrid) }\end{array}$ & 37.87 & 8.65 & 27.82 & 83.88 & 4.36 & 27.13 & 5.40 \\
\hline S.Em. \pm & 0.14 & 0.04 & 0.28 & 0.58 & 0.17 & 0.34 & 0.15 \\
\hline CD at 5\% & 0.41 & 0.11 & NS & NS & NS & NS & NS \\
\hline \multicolumn{8}{|l|}{ Plant density } \\
\hline NP $100 \%$ & 38.81 & 7.54 & 27.13 & 82.68 & 4.61 & 27.06 & 5.77 \\
\hline HDP $150 \%$ & 39.00 & 7.50 & 27.17 & 83.98 & 4.56 & 26.88 & 5.50 \\
\hline HDP $200 \%$ & 39.09 & 7.35 & 27.96 & 83.83 & 4.61 & 28.02 & 5.63 \\
\hline S.Em. \pm & 0.14 & 0.04 & 0.28 & 0.58 & 0.17 & 0.34 & 0.15 \\
\hline CD at $5 \%$ & NS & 0.11 & NS & NS & NS & NS & NS \\
\hline \multicolumn{8}{|l|}{ Interaction } \\
\hline S. Em. \pm & 0.24 & 0.06 & 0.49 & 1.00 & 0.29 & 0.59 & 0.25 \\
\hline CD at 5\% & NS & NS & NS & NS & NS & NS & NS \\
\hline Mean & 38.96 & 7.46 & 27.42 & 83.50 & 4.59 & 27.32 & 5.63 \\
\hline
\end{tabular}

\section{Thermal use efficiency}

Thermal use efficiency was found to be higher in genotype AKA-7 with respect to both seed cotton and biomass production. It was followed by genotypes Balwan and AKH-081. Treatments of the different plant densities, thermal use efficiency in terms of 
seed cotton yield and biomass production was higher with HDP-200\% followed by HDP$150 \%$ and NP-100\%. The application of thermal use efficiency indices provides a basis for determining the integrated effect of temperature, radiation or photoperiod on phonological behaviour of the crop, providing efficiency of hear energy consumption by the crop under different growing environment.

\section{Yield Attributes}

Bt. cotton Balwan recorded significantly higher number of picked bolls, boll weight and higher seed cotton weight $(17.59,3.21$ and $56.49 \mathrm{~g})$ as compared to arboreum genotype AKA-7 (6.78, 2.01 and $14.34 \mathrm{~g}$ ) and hirsutum genotype AKH-081 $(5.58,2.10 \mathrm{~g}$ and $11.44 \mathrm{~g}$ ). Number of picked bolls and yield in AKA-7 was significantly more than AKH-081, which recorded least number of picked bolls plant ${ }^{-1}$. However, evaluation data indicated that boll weight was recorded in two genotypes i.e. arboreum cotton (AKA-7) and hirsutum cotton were statistically at par with each other.

The differences among genotypes for number of picked boll per plant, boll weight and yield per plant might have been due to the differences in genetic potential of the genotypes and comparatively high retention of bolls by $B t$. cotton genotypes. Significant differences among cultivars number of bolls per plant and yield per plant and boll weight were also recorded by Copur (2006), Hofs et al., (2006) and Ban et al., (2015).

Number of picked bolls per plant and seed cotton weight per plant $(\mathrm{g})$ was the maximum with normal planting density of 100 percent population (11.67 and $33.97 \mathrm{~g}$ ) which was significantly more over high planting density of 150 and 200 percent i.e. $9.77 \& 27.44$ and $8.51 \& 20.87 \mathrm{~g}$ of normal population. Normal or optimum plant population while optimizing resource use produced more boll number and boll weight that reflected in higher seed cotton weight plant $^{-1}$. Under high density population probably due to reduced availability of resources to individual plant resultantly fewer boll number and smaller boll weight reflected in reduced seed cotton weight plant $^{-1}$. The aforesaid results are supported by findings of Giri et al., (2008) and Darawsheh et al., (2009).

However, normal planting at 100 per cent population recorded the maximum boll weight which was at par with 150 per cent planting density and significantly higher over 200 per cent planting density. According to Rose et al., (2003) under ultra-narrow system in cotton less light is available to leaves lower in the canopy that are important for supporting boll growth. This may be one reason that boll size is smaller despite there being fewer bolls plant $^{-1}$. Venugopalan et al., (2011) reported that in both $G$. hirsutum and G.arboreum genotypes the boll weight and harvest index decrease with increasing plant density. Paslawar et al., (2015) also observed that boll weight increased with decreased plant densities.

\section{Yield studies}

All the cotton genotype differed from each other for seed cotton yield. AKA-7 registered significantly higher seed cotton yield (1715 $\left.\mathrm{kg} \mathrm{ha}^{-1}\right)$ than Bt. cotton Balwan (1571 $\mathrm{kg} \mathrm{ha}^{-}$ ${ }^{1}$.). The latter two genotypes were statistically at par. Whereas, genotype AKA-7 recorded significantly higher cotton stalk yield (3038 $\mathrm{kg} \mathrm{ha}^{-1}$ ) and biological yield (4753 $\mathrm{kg} \mathrm{ha}^{-1}$ ). Among the three genotypes $B t$. cotton Balwan produced maximum leaf area plant ${ }^{-1}$, dry matter weight plant $^{-1}$, greater number and weight of bolls and higher seed cotton weight plant $^{-1}$ followed by genotypes AKA-7 and AKH-081. Genotype AKA-7 although had lower leaf area plant ${ }^{-1}$, smaller boll size and 
fewer bolls plant ${ }^{-1}$ and seed cotton weight plant $^{-1}$, however its conventional density accommodating markedly higher per unit population than in Balwan, compensated for lower values of yield attributes plant ${ }^{-1}$ and produced higher yield level with better tolerance to the short term weather fluctuations during the growing season. Comparatively lower yield level in AKH-081 appears to be more due to incidence of boll worm complex, besides its genetic potential. These results are supported by Singh et al., (2012) and Venugopalan et al., (2011).

However, Bt. cotton genotype Balwan recorded significantly higher harvest index (39.50 \%), whereas hirsutum non Bt. genotype AKH-081 recorded the lowest harvest index (35.12\%). As such both non Bt. genotypes i.e. arboreum AKA-7 (36.31\%) and hirsutum $\mathrm{AKH}-081$ were statically at par. Higher harvest index shows better translocation efficiency in genotype Balwan.

High density planting at $200 \%$ of normal density produced maximum seed cotton yield $\left(1802 \mathrm{~kg} \mathrm{ha}^{-1}\right)$, cotton stalk yield $(3338 \mathrm{~kg}$ $\mathrm{ha}^{-1}$ ) and biological yield (5140 $\mathrm{kg} \mathrm{ha}^{-1}$ ). However, seed cotton yield was at par with yield of Bt. cotton (1679 $\mathrm{kg} \mathrm{ha}^{-1}$ ) under $150 \%$ of normal plant density. Normal plant density $100 \%$ yielded the least seed cotton (1271 $\left.\mathrm{kg}^{-1}\right)$. The high density planting treatments generally had smaller individual boll weight and fewer bolls plant ${ }^{-1}$. However, the increased number of plants compensated for fewer boll number and smaller boll size and cumulatively yield output was significantly higher in both the high density planting treatments as compared to conventional 100\% planting density. These results are in agreement with reports of Bhalerao et al., (2012) and Paslawar et al., (2015).

Whereas, high density planting at $100 \%$ of normal density produced maximum harvest index $(38.08 \%)$ which are significantly higher than $200 \%$ high density planting $(35.07 \%)$ an statistically at par with high density planting of $150 \%$ (37.77\%). The finding shows better translocation efficiently under conventional planting (100\%) as compared to high planting densities (150\% and $200 \%$ ). Increase of leaf area index associated with high population densities has been showed to reduce the efficiency of photosynthesis photon flux density interceptions for plant area. In this case greater proportion of photon assimilates is directed to the vegetative growth rather than reproductive (Darawsheh et al., 2007) thus reducing harvesting index. Venugopalan et al., (2013) also reported that harvest index decreases with increase in plant density.

\section{Quality studies}

The highest value of ginning outturn was obtained in case of genotype AKA-7 and it was followed by AKH-081 and Balwan i.e. 40.11, 38.92 and 37.87 per cent, respectively. However, Bt. cotton genotype Balwan recorded high seed index followed by $G$. hirsutum AKH-081 and G. arboreum AKA-7 i.e. $8.65,7.64$ and $6.10 \mathrm{~g}$, respectively.

Ginning outturn did not differ significantly under different plant densities. Numerically high density planting at 200 per cent recorded maximum ginning outturn (39.09) followed by high density planting at 150 per cent (39.00\%) and normal planting density at 100 per cent (38.81). Genetic differences as well as plant density were statistically not significant in respect of $2.5 \%$ staple length, uniformity index, micro-naire, bundle strength, and elongation. Reddy and Gopinath (2008) and Reddy and Kumar (2010) also reported that ginning percentage was free of population pressure. However, normal planting density at 100 per cent population level noted higher seed index (7.54g). It was 
statistically at par with high density planting at 150 per cent population level $(7.51 \mathrm{~g})$ and significantly more than 200 per cent population level (7.35g). Treatment 150 per cent planting density also proved superior to 200 per cent planting density. This appears in contrast to Darawsheh et al., (2009) who observed that plants in narrow high population density produced lower fibre proportions or higher seed proportions.

Thus, it was concluded that, cotton genotype AKA-7 with 150 to 200 per cent planting density recorded higher seed cotton yield with maximum fraction of PAR, lowest fraction transmitted PAR and canopy temperature with high canopy temperature depression and greater tolerance to environment stress with comparative to genotypes $\mathrm{AKH}-081$ and $B t$. Balwan. Genotypes differences as well as plant density did not influence the fibre quality parameters.

\section{References}

Ban, Yogesh G., D.P. Nawalkar, B.M. Mote, V. Kumar and V. Narwade 2015. Crop phenology, thermal requirement, yield and fiber properties of Cotton (Gossypium hirsutum) genotypes as influenced by different environments. Ind. J. Plant Physiology. 20 (2): 137144.

Bendarz C.W., D.C. Bridges and S.M. Brown, 2000. Analysis of cotton yield stability across population densities. Agronomy Journal. 92: 128.135.

Bhalerao P.D., P.W. Deshsmukh, Godavari S. Gaikwad and S.R. Imade, 2012. Response of Bt. cotton (Gossypium hirsutum L.) to spacing and fertilizer levels under rainfed condition. Indian Journal of Agronomy. 57 (2): 18-21.

Bonde W.C. and A.R. Raju, 1996. Effect of varying plant densities and fertilizer levels on rainfed cotton yields in vertisols. J. Indian Soc. Cotton Improvement. 21: 50-55.

Buttar, G.S., C.J. Singh, M.S. Ahuja and K.S. Saini, 2005.Canopy Temperature: A method to estimate plant water stress and scheduling irrigation in Cotton and Wheat. Jour. Agric. Physics, 5(1): 7983.

Clay, P.A., K.M. Young and E.R. Taylor 2006. Effect of heat unit accumulation on cotton defoliation lint yield and fibe quality. Arizona Cotton Report, (P145), Coop Ext., Univ Arizona, Tucson, USA: $245-250$.

Copur, O. 2006. Determination of yield and yield components of some cotton cultivars in semi-arid conditions. Pak. J. Biol. Sci. 9(14) 2572-2578.

Darawsheh, M.K., E.M. Khah, G. Aivalakis, D. Chanchalis and F. Sallaku, 2009. Cotton row spacing and plant density cropping systems I. Effects on accumulation and partitioning of dry mass and LAI. J. Food Agric. Environ., 7, 258-261.

Giri, A.N., R.L. Aundhekar, P.S. Kapse and S.B. Suryavanshi, 2008. Response of Bt cotton hybrids to plant densities and fertilizer levels. J.Cotton Res. Dev. 22(1): 45-47.

Han, Li, C.F. Wang, J. Wang ji, Y.Y. Li, X.L. Zhou, 2007. The study on differences of the canopy temperature and physiological characteristics of cotton. Acta Agricultural Boreali-Occindentalis Sinica, 16: 85-88.

Hofs, J.L., B. Hau and D. Marais, 2006. Boll distribution patterns in $\mathrm{Bt}$ and non-Bt cotton cultivars; I. Study on commercial irrigated farming systems in South Africa. Field Crops Res., 98 (2 \& 3): 203-209.

Jahedi, M.B., F. Vazin and M.R. Ramezani, 2013. Effect of row spacing on the yield of cotton cultivars. Cercetari 
Agronomice in Moldova XLVI, No. 4 (156):31-38.

Munir, M.K., M. Tahir, M.F. Saleeem and M. Yaseen, 2015. Growth, yield and earliness response of cotton to row spacing and nitrogen management. The Journal of Animal and Plant Sciences. 25(3): 729-738.

Mygdakos, E., C. Avgoulas, K. Adamidis and G. Ekonomou, 2004. Cotton cultivation on narrow rows as an alternative culture method: Production and Economics. J. Food Agric \& Environ. 2: 198-201.

Paslawar, A.N., A.S. Deotalu and P.W. Nemade, 2015. High density planting of cotton variety $\mathrm{AKH}-081$ under rainfed condition of Vidarbha, ISSN 0972 5210, Plant archives. Vol.15, No.2, PP1075-1077.

Pettigrew, H.T., Meredith Jr., W.R. Jr., and Zeng Linghe, 2013.Response of absolute and modern cotton genotypes to varying plant densities. J. Cotton. Sci. 17: 253-262.

Reddy, R.R.P and D.B. Kumar, 2010. Yield and economics of $\mathrm{Bt}$ cotton as influenced by spacing and nutritional levels. PKV Res.J.34 (1): 20-22.

Reddy, R.R.P and M. Gopinath, 2008. Influence of fertilizers and plant geometry on performance of $B t$. cotton hybrids. J. Cotton. Res. Dev. 22(1): 7880.

Rose Roche, Michael Bange, Stephen Milroy and Graeme Hammer, 2003.Cotton growth in UNR systems. The Australian
Cotton Grower. October-November 2003.

Singh Jagvir, Shilpa Babar, Shalu Abraham, M.V. Venugopalan, and G. Majumdar, 2012. Fertilization of high density rainfed cotton grown on Vertisols of India. Better Crops. 96 (2): 26-28.

Venugopalan M.V., A.H. Prakash, K.R. Kranthi, Rachana Deshmukh, M.S. Yadav and N.R. Tendulkar, 2011. Evaluation of cotton genotypes for high density planting systems on rainfed Vertisols of Central India. In World Cotton Research Conference-5 (book of papers), Mumbai, 7-11 November, 2011: 341-346.

Venugopalan M.V., K.R. Kranthi, Subhangi Lakade and N.R. Tendulkar, 2013. High density planting system in cotton. The Brazil experience and Indian Initiatives. Cotton Res. J.5 (2): 172-185.

Yang, Guo Zheng, Luo Xue Jiao, Nie Yinchuan and Zhang Xian long 2014. Effects of plant density on yield and canopy micro environment in hybrid cotton. Journal of Intergrative Agriculture. Advanced online Publication: Doi: 10.1016/S2095-3119 (13) 60727-3.

Zhang M., L. Duan, X. Tian, Z. Li 2006. Unicanzole induced tolerance of soybean to water deficit stress in relation to changes in photosynthesis, hormones and antioxidant system. Journal plant physiology. 164: 709-701.

\section{How to cite this article:}

Karunakar, A.P., Arvind Kumar, A.B. Turkhede, M.B. Nagdeve and Mali, R.S. 2018. AgroMeteorological Studies in Different Cotton Species under HDPS. Int.J.Curr.Microbiol.App.Sci. 7(08): 4605-4616. doi: https://doi.org/10.20546/ijcmas.2018.708.486 